\title{
Clinical evaluation of chemo-sterilization through histomorphology and hormonal changes in bucks
}

\author{
M. Hasan, M. A. H. Miah, M. M. Alam \& N. S. Juyena ${ }^{\#}$ \\ Department of Surgery and Obstetrics, Faculty of Veterinary Science, Bangladesh Agricultural University, Mymensingh- \\ 2202, Bangladesh
}

(Submitted 14 June 2018; Accepted 8 April 2019; Published 18 December 2020)

\begin{abstract}
Copyright resides with the authors in terms of the Creative Commons Attribution 4.0 South African Licence.
See: http://creativecommons.org/licenses/by/4.0/za

Condition of use: The user may copy, distribute, transmit and adapt the work, but must recognise the authors and the South African Journal of Animal Science.
\end{abstract}

\begin{abstract}
The study was aimed to evaluate methods for nonsurgical castration of Black Bengal bucks by intratesticular injection of calcium chloride, sodium chloride, citric acid solutions or sterile deionized water. Twelve healthy bucks were randomly allotted to groups $A, B, C$, and D, consisting of three bucks each. The local anesthetic, $2 \%$ lidocaine hydrochloride, was infused into the spermatic cord of each buck, followed by bilateral intra-testicular injections of $30 \%$ calcium chloride $\left(\mathrm{CaCl}_{2}\right), 25 \%$ sodium chloride $(\mathrm{NaCl}), 50 \%$ citric acid $\left(\mathrm{C}_{6} \mathrm{H}_{8} \mathrm{O}_{7}\right)$ solutions, and sterile deionized water dosed at $2 \mathrm{ml}$ per testis in groups $A, B, C$ and $D$ respectively. To evaluate the efficacy of chemical agents on the inactivation of testes, clinical parameters, changes in scrotal circumference, testicular fine needle aspiration (TFNA), histopathology and serum concentration of testosterone and $\mathrm{LH}$ were monitored. A significant decrease in the scrotal circumference was observed between the intra-testicular injection and day 14 in all the bucks. Absence of spermatogenic cells and spermatozoa in the testicular biopsy was observed on day 14 post injection in the bucks, except for one in group C. Histopathology revealed massive destruction of seminiferous tubules and disorganization of the testicular parenchyma. Serum testosterone concentration declined significantly on day 14 compared with day 0 . Consequently, the gradual elevation in serum $\mathrm{LH}$ concentration was significant. Thus, intra-testicular injections of $\mathrm{CaCl}_{2}$ and $\mathrm{NaCl}$ were more effective than $\mathrm{C}_{6} \mathrm{H}_{8} \mathrm{O}_{7}$ in inducing chemical-based nonsurgical castration.
\end{abstract}

Keywords: castration, intra-testicular injection, luteinizing hormone, testicular fine needle aspiration, testosterone

\#Corresponding author: juyenahabib@yahoo.com

\section{Introduction}

'Castration' refers to any procedure that makes the testicles inactive by damaging them irreparably or causing them to atrophy because of stricture of the blood supply (Currah et al., 2009). Bilateral orchiectomy is the most common technique to suppress testosterone production, thus preventing reproduction of genetically inferior animals or reducing their aggressiveness (Bretschneider, 2005). However, orchiectomy is a traumatic procedure that requires a qualified technician to decrease animal suffering. Potential complications associated with surgical castration include haemorrhage, excessive swelling or oedema, infection, poor wound healing, and failure (Stafford \& Mellor, 2005).

Chemical-based nonsurgical castration involves injecting a sclerosing or toxic agent into the testicular parenchyma to cause irreversible damage and functional loss (Fordyce et al., 1989). Chemical sterilants include cadmium chloride (Kar, 1961), ferric chloride and ferrous sulphate (Kar et al., 1965), danazol (Dixit et al., 1975), bacillus Calmette Guerin (BCG) (Naz \& Talwar, 1981), glycerol (Immegart \& Threlfall, 2000), formalin (ljaz et al., 2000; Bakir et al., 2002), lactic acid (Fordyce et al., 1989), $\mathrm{NaCl}$ (Neto et al., 2014), and $\mathrm{CaCl}_{2}$ (Koger, 1978; Fahim et al., 1982; Jana et al., 2002; Leoci et al., 2014; Cavalieri, 2017). These sterilants caused some pain and pyrexia, and even orchitis after intra-testicular injection. Some agents (e.g. cadmium chloride, glycerol, and lactic acid) caused selective destruction of the testicular parenchyma (Immegart \& Threlfall, 2000). The primary practical advantages of intra-testicular injection over surgery are affordability, elimination of the need for anaesthesia and sterile conditions, and least post-operative care. This technique is easy to inject and requires little training. The sterilants are not rapidly irritant to the skin and 
complications may be avoided if spilled solution is wiped away immediately (Jana \& Samanta, 2011). The efficacy of such sterilants has been observed in farm animals (Martins et al., 2011; Neto et al., 2014; Oliveira et al., 2017). However, there is no record of the use of an organic acid such as $\mathrm{C}_{6} \mathrm{H}_{8} \mathrm{O}_{7}$ as a chemosterilant. Hence the present research was designed to explore and compare the changes in clinical parameters, histomorphology and concentration of testosterone and luteinizing hormone (LH) in serum after intratesticular injection of $\mathrm{CaCl}_{2}, \mathrm{NaCl}$ and $\mathrm{C}_{6} \mathrm{H}_{8} \mathrm{O}_{7}$ solutions in Black Bengal bucks.

\section{Materials and Methods}

The present study was designed with the approval of the Animal Experimentation Ethics Committee (AEEC), Department of Surgery and Obstetrics, Bangladesh Agricultural University, Mymensingh-2202 (protocol number 01/2016/AEEC) in accordance with the UK Animals (Scientific Procedures) Act, 1986, and associated guidelines, and EU Directive 2010/63/EU for animal experiments.

The research work was carried out in the Department of Surgery and Obstetrics, Bangladesh Agricultural University (BAU), Mymensingh, from February 2016 to May 2016 in spring. The study population consisted of twelve apparently healthy bucks, purchased from a local market, and aged three to four months. The bucks were kept in the shed of the Department of Surgery and Obstetrics, BAU, and were managed under grazing and water ad libitum. The anthelmintic drug Ivermectin $0.2 \mathrm{mg} / \mathrm{kg}$ (A-Mectin ${ }^{\circledR}$, ACME Laboratories Ltd., Bangladesh) was injected subcutaneously as routine management practice in each buck. PPR vaccine and tetanus toxoid (Tetavex ${ }^{\circledR}$, Sanofi Aventis) had been administered to each buck one month before the experiment began.

After acclimatization, twelve bucks were divided randomly into groups $A, B, C$ and $D$, consisting of three bucks in each group. Then local infiltration with $2 \%$ lidocaine hydrochloride in the spermatic cord was applied to each buck, followed by bilateral intra-testicular injection of $40 \% \mathrm{CaCl}_{2}, 30 \% \mathrm{NaCl}, 50 \% \mathrm{C}_{6} \mathrm{H}_{8} \mathrm{O}_{7}$ solutions, and sterile deionized water dosed at $2.0 \mathrm{ml}$ per testis in groups $\mathrm{A}, \mathrm{B}, \mathrm{C}$, and $\mathrm{D}$, respectively (Jana et al., 2002; Neto et al., 2014). Administration of the treatments was accomplished by linear infiltration over the entire route of testes while withdrawing the needle from the proximal to the distal end. To study the comparative efficacy of chemical agents on the inactivation of the testes, clinical parameters, changes in scrotal circumference, TFNA, and histopathology were monitored, and assays of testosterone and LH were performed using the ELISA technique. Scrotal circumference was measured with a scrotal circumference measuring tape on day 0 and on days 7 and 14 post injection. The testes were held firmly with one hand and the scrotal circumference was measured in the mid testis region. Rectal temperature, heart rate, respiration rate and lesions on the scrotum were also measured prior to the intra-testicular injection on day 0 and on days 7 and 14 post injection in all the bucks.

Testicular fine needle aspiration was done in both testes of all bucks before the injection and on day 14. A 21-gauge butterfly needle attached to a $20 \mathrm{ml}$ syringe was introduced smoothly into the testis perpendicular to the scrotal skin (Larkin, 1994). When the needle was fully inserted, testicular tissue was aspirated for the unidirectional technique. The aspirate was then expelled onto a clean glass slide for smearing. For the multidirectional technique, the needle was inserted into the testis in three to four directions. Samples ( $n=48 ; 24$ unidirectional and 24 multidirectional smears obtained from twelve bucks) were then air-dried and stained with modified May-Grünwald-Giemsa (MGG) stain (Foresta, 1993; Stelletta et al., 2011).

The TFNA smears were observed under a light microscope at $1000 \times$ magnification using immersion oil to detect the presence of spermatozoa. An adequate and informative TFNA specimen was defined by observing several clusters or cords of cells that contained 10 or more cells. At least ten microscopic fields of each smear from each testis were observed for interpretation.

Orchiectomy was performed in all bucks on day 14 after performing TFNA to collect testes samples for the histomorphological study. The samples excluded the TFNA areas to avoid tissue damage caused by biopsies. A routine Haematoxylin and Eosin staining technique was performed after processing the testicular tissues, which were taken as cross-sections from each mid-testis region. The stained sections were observed under light microscopy at $400 \times$ magnification. At least five microscopic views were considered from each sample.

Around $2 \mathrm{ml}$ blood was collected aseptically into vacuum blood collection tubes with a clot activator from the jugular vein of each buck on day 0 , and on days 7 and 14 post injection. After collection, the blood was centrifuged at $3000 \mathrm{rpm}$ for 20 minutes to collect serum. Serum was collected in Eppendorf tubes and preserved at $-20^{\circ} \mathrm{C}$ (Talukder et al., 2018; Hasan et al., 2016).

The serum concentrations of testosterone and LH were measured with an ELISA reader (Ultra Microplate reader, Biotek Instruments, Inc., Winooski, USA). The ELISA kits for testosterone and LH were supplied by NovaTec Immunodiagnostica GmbH (Germany). The essential reagents for testosterone assay are a biotinylated antibody (anti-testosterone biotinylated purified rabbit IgG conjugate), an enzyme-antigen 
(horseradish peroxidase), a conjugate, and a serum containing the native antigen. The LH assay system utilizes one anti-LH antibody for the solid phase (microtiter wells) immobilization and another mouse monoclonal anti-LH antibody in the antibody-enzyme conjugate solution. Assays were performed according to standardized instructions. Testosterone concentration (in $\mathrm{ng} / \mathrm{ml}$ ) was calculated using the formula $\mathrm{y}=$ $0.011+104.627^{*} \mathrm{x}$ from a standard curve with seven standards supplied with the testosterone ELISA kit box. LH concentration (in $\mathrm{mIU} / \mathrm{ml}$ ) was calculated with the formula $\mathrm{y}=2.11+115.805{ }^{*} \mathrm{x}$ from a standard curve with six standards supplied with the LH ELISA kit box. The absorbance of the standards and samples was measured spectrophotometrically at $450 \mathrm{~nm}$. The intra-assay coefficients of variation (CV) $(n=12)$ were $6.77 \%$ and $9.22 \%$ and inter-assay $\mathrm{CV}$ were $7.48 \%$ and $9.21 \%$ for testosterone and $\mathrm{LH}$, respectively.

The clinical parameters, scrotal circumference and concentrations of testosterone and LH in serum were analysed through repeated measurement one-way analysis of variance (ANOVA) using SPSS (version 20; IBM Corp., Armonk, New York, USA). The $P$ value $<0.05$ was considered significant.

\section{Results and Discussion}

Chemo-sterilization altered the scrotal circumference (Figure 1), testicular histomorphology and concentrations of testosterone and $\mathrm{LH}$ in the serum after a single bilateral injection of $\mathrm{CaCl}_{2}, \mathrm{NaCl}$, and $\mathrm{C} 6 \mathrm{H} 8 \mathrm{O} 7$ in Black Bengal bucks.

No differences $(P>0.05)$ in rectal temperature, heart rate and respiration rate were observed in the bucks in any group. Palpation of the testes after the injections revealed swollen, hard, adherent, and nonfreely moving testes owing to the post localized inflammatory process. The significant $(P<0.05, \mathrm{~F}=9.27)$ decrease in scrotal circumference (Figure 1) in the bucks on day 14 might be due to atrophy of the testes. These findings are supported by previous studies on bucks (Mohammed \& James, 2013).

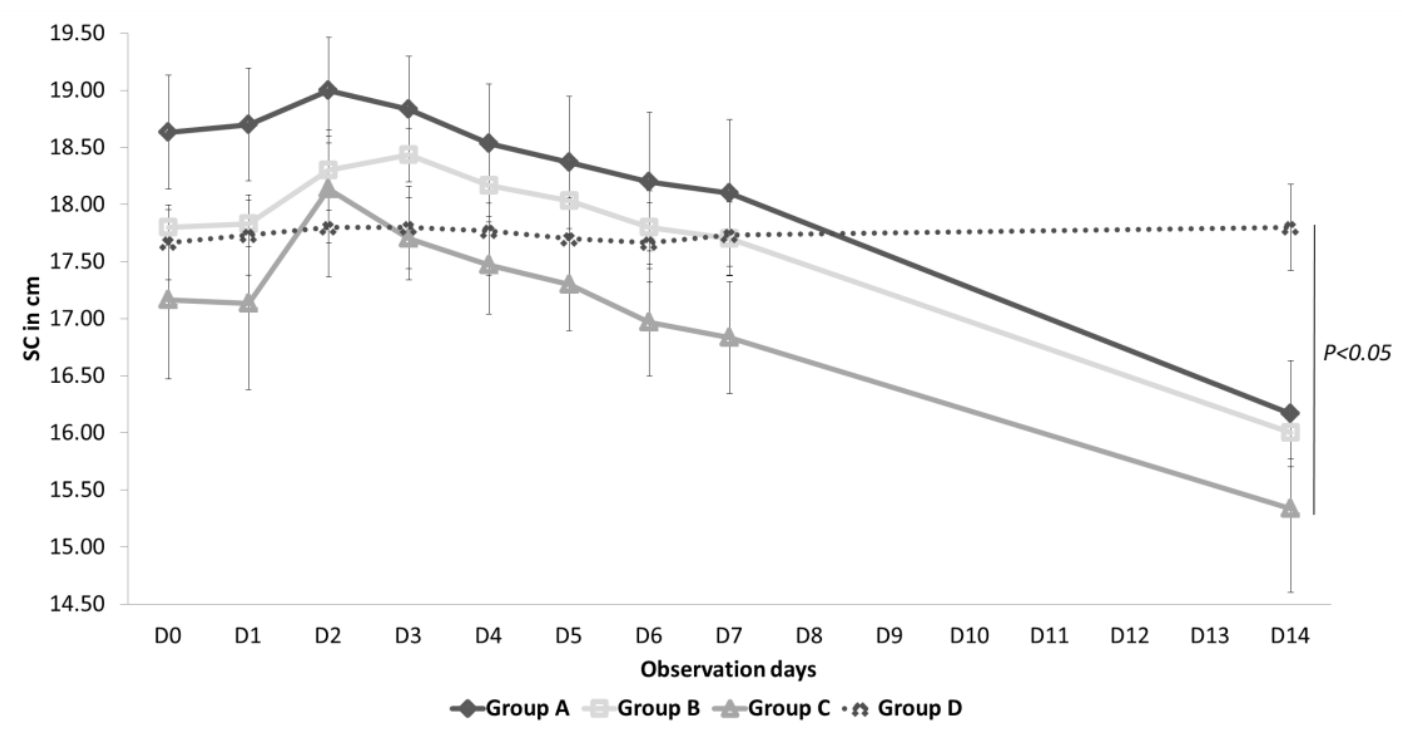

Figure 1 Gradual changes $(P<0.05)$ in scrotal circumference of bucks from day 0 to day 14

SC: scrotal circumference, Group A: intra-testicular injection of 30\% calcium chloride solution, Group B: intratesticular injection of $25 \%$ sodium chloride solution, Group C: intra-testicular injection of $50 \%$ citric acid solution, Group D intra-testicular injection of deionized water

The absence of spermatogenic cells and spermatozoa was observed after 14 days in TFNA samples from groups $A$ (Figure $2 b$ ) and $B$ (Figure $3 b$ ). However, spermatozoa were present in TFNA samples of only one buck in group $C$ (Figure $4 b$ ), whereas spermatogenic cells and spermatozoa were present in the TFNA samples of control bucks (Figure $5 b$ ). Gross testicular changes observed in the present study were consistent with previous findings (Tepsumethanon et al., 2005; Mohammed \& James, 2013). Hard and tense testes on day 1 post injection were due to inflammation and oedema, indicating severe degeneration of testicular tissue. 
a

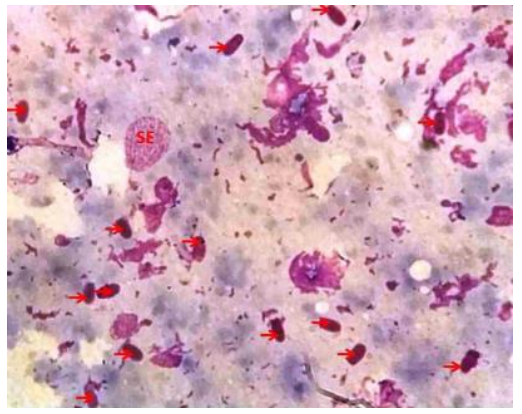

b

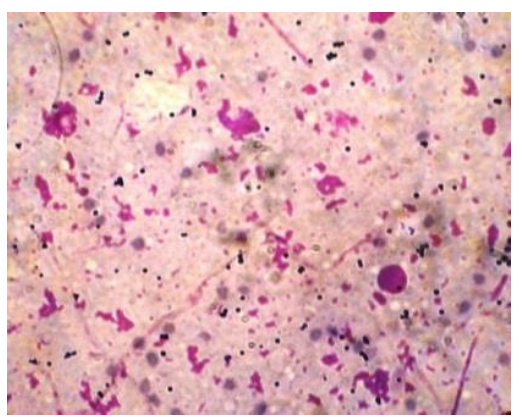

Figure 2 Randomly selected micrograph of smear of cells collected via fine needle aspiration of testicular tissue collected (a) before and (b) 14 days after intra-testicular injection of $30 \%$ Calcium chloride solution

$\mathrm{SE}=$ sertoli cell; $\rightarrow=$ spermatozoa
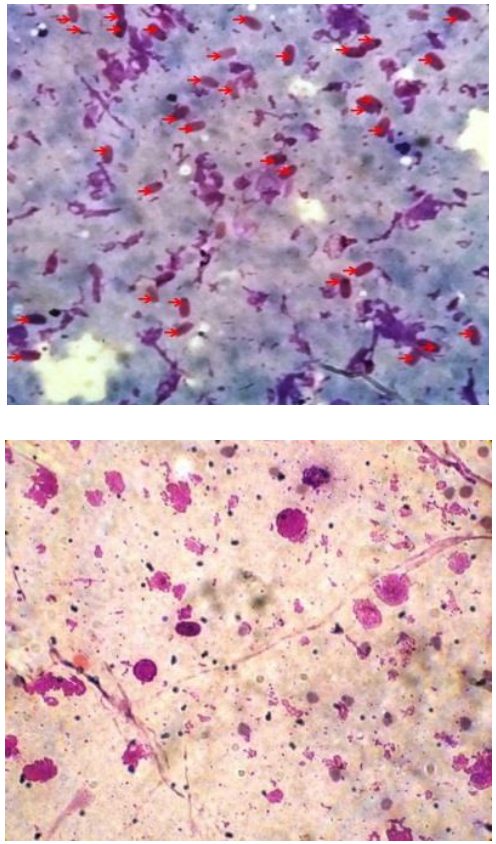

Figure 4 Randomly selected micrograph of smear of cells collected via fine needle aspiration of testicular tissue collected a) before and b) 14 days after intra-testicular injection of $50 \%$ citric acid solution

$\mathrm{SE}=$ sertoli cell $; \rightarrow=$ spermatozoa
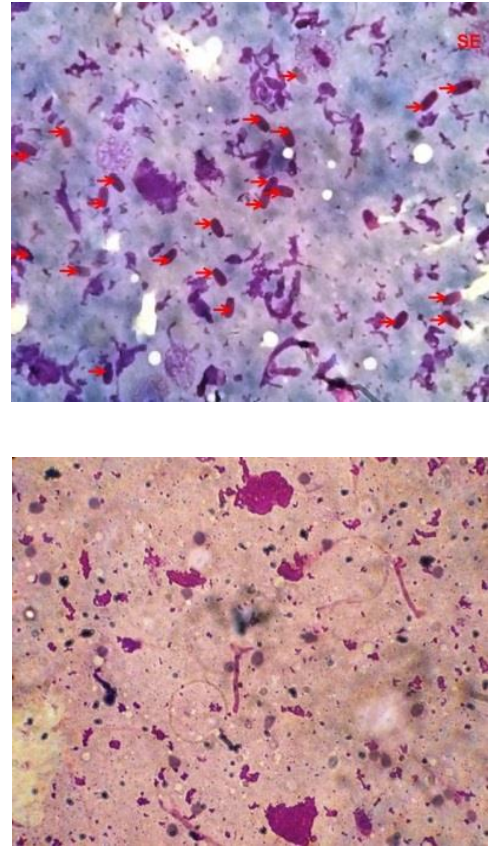

Figure 3 Randomly selected micrograph of smear of cells collected via fine needle aspiration of testicular tissue collected a) before and b) 14 days after intratesticular injection of $25 \%$ Sodium chloride solution SE $=$ sertoli cell; $\rightarrow=$ spermatozoa
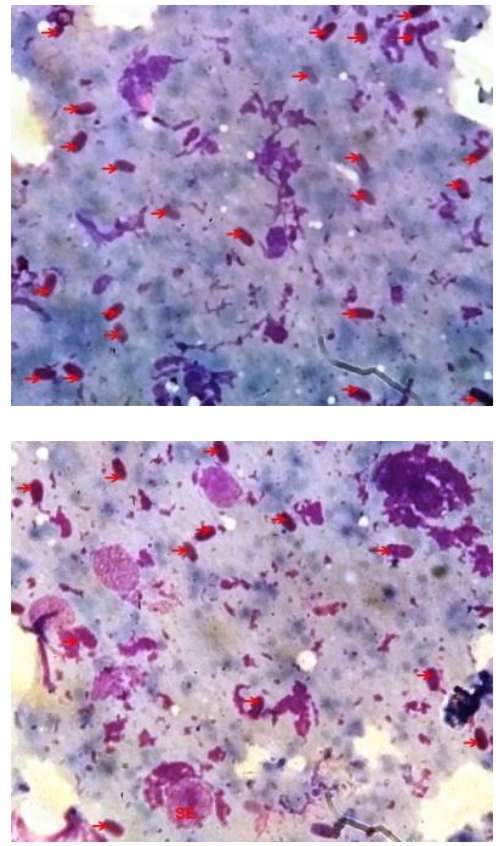

Figure 5 Randomly selected micrograph of smear of cells collected via fine needle aspiration of testicular tissue collected a) before and b) 14 days after intratesticular injection of deionized water

$\mathrm{SE}=$ sertoli cell; $\rightarrow=$ spermatozoa 
There was massive necrosis of convoluted seminiferous tubules with loss of their distinct borders. Damaged seminiferous tubules, disorganization of parenchyma cells, infiltration of inflammatory cells in the tubules and congested blood vessels were observed in the Haematoxylin-Eosin stained histologic section of testis from group A (Figure 6). In group B, damaged seminiferous tubules, disorganization of parenchyma cells and infiltration of inflammatory cells in the tubules were seen (Figure 7). In group C, damaged seminiferous tubules, infiltration of inflammatory cells in the mid-tubules and congested blood vessels were found (Figure 8). The levels of necrosis and inflammatory response were severe in group A, moderate in group B, and milder in group C. Intact seminiferous tubules with distinct borders and normal testicular parenchyma were observed in the histologic section from control group D (Figure 9). However, in the present study, lack of spermatogenic cells and spermatozoa were observed on day 14 post injection. Histopathology was performed to justify the TFNA findings. The findings conformed with studies with $\mathrm{CaCl}_{2}$ (Mitra \& Samanta, 2000; Jana \& Samanta, 2011) and NaCl (Emir et al., 2008; Neto et al. 2014). However, mild inflammatory zones in group $\mathrm{C}$ indicated that $\mathrm{C}_{6} \mathrm{H}_{8} \mathrm{O}_{7}$ was less effective than $\mathrm{CaCl}_{2}$ and $\mathrm{NaCl}$. The extent of cellular destruction as seen in group $A$ and $B$ could induce infertility more effectively than group $\mathrm{C}$. Thus, the application of chemical-based castration in farm animals may be useful in the absence of conventional castration tools.

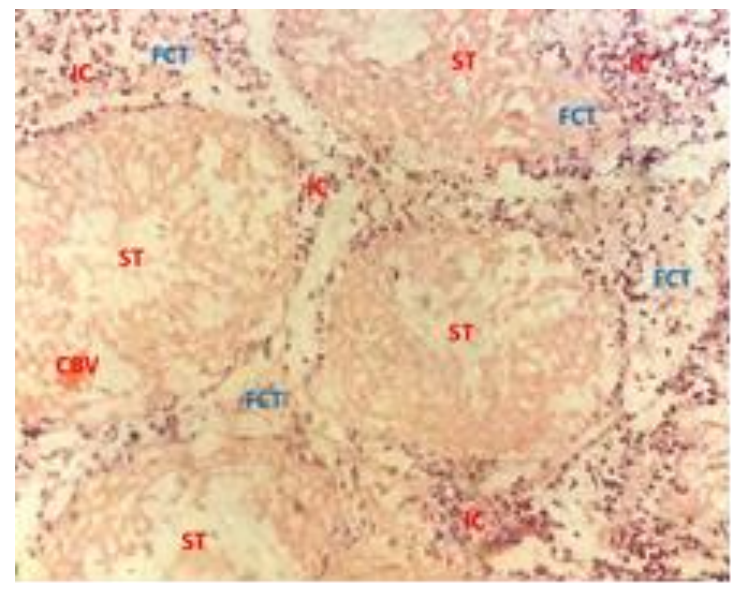

Figure 6 Haematoxylin-Eosin-stained histologic section of testis of Black Bengal bucks after intra-testicular injection of $30 \%$ calcium chloride solution

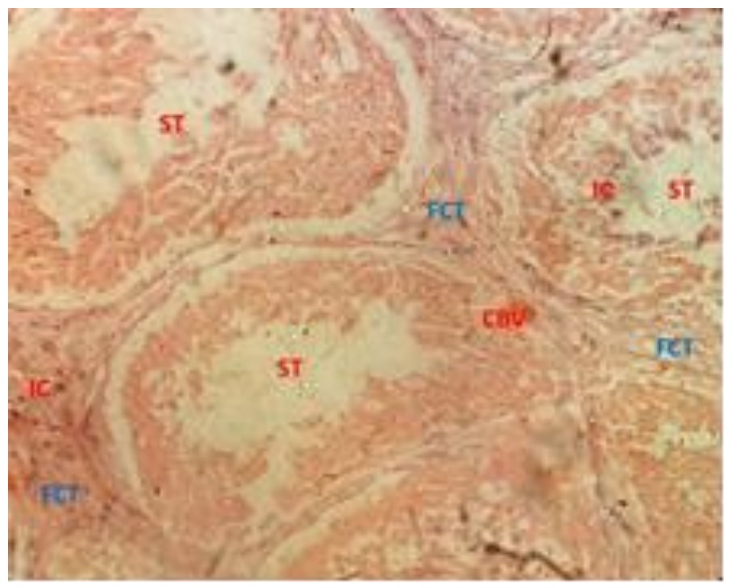

Figure 7 Haematoxylin-Eosin-stained histologic section of testis of Black Bengal bucks after intra-testicular injection of $25 \%$ sodium chloride solution

ST: seminiferous tubule, FCT: fibrous connective tissue, CBV: congested blood vessel, IC: interstitial cell

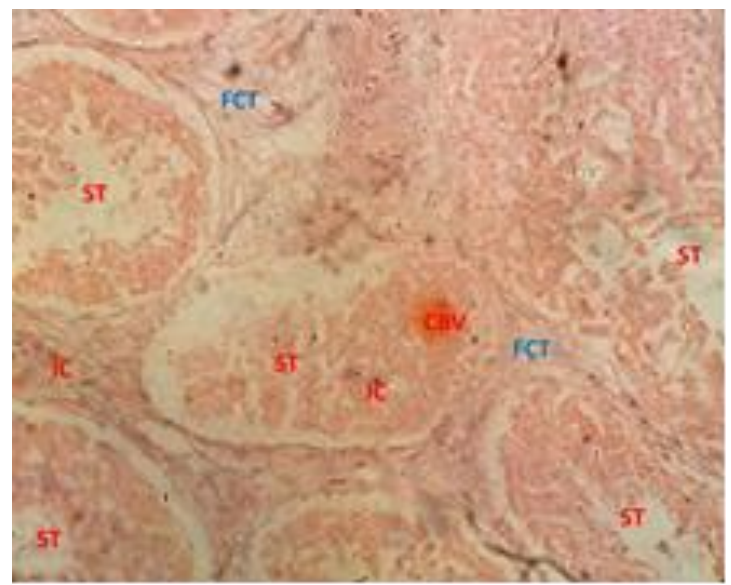

Figure 8 Haematoxylin-Eosin-stained histologic section of testis of Black Bengal bucks after $50 \%$ citric acid solution

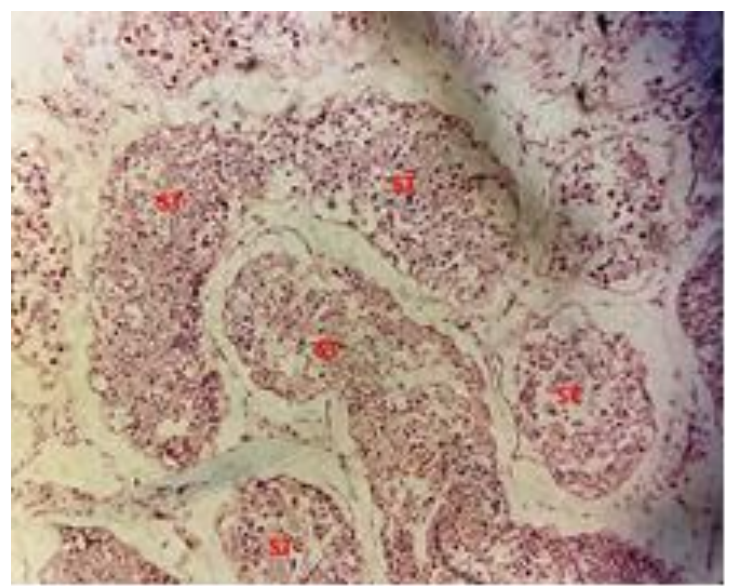

Figure 9 Haematoxylin-Eosin-stained histologic section of testis of Black Bengal bucks after intra-testicular injection of deionized water

ST: seminiferous tubule, FCT: fibrous connective tissue, CBV: congested blood vessel, IC: interstitial cell 
The testosterone concentration $(\mathrm{ng} / \mathrm{ml})$ in serum decreased $(P<0.01, \mathrm{~F}$ value $=47.55)$ from $5.92 \pm$ $0.06 \mathrm{ng} / \mathrm{ml}, 5.84 \pm 0.04 \mathrm{ng} / \mathrm{ml}$, and $5.87 \pm 0.05 \mathrm{ng} / \mathrm{ml}$ on day 0 in groups $A, B$, and $C$ to $4.27 \pm 0.11 \mathrm{ng} / \mathrm{ml}$, $3.98 \pm 0.05 \mathrm{ng} / \mathrm{ml}$, and $4.51 \pm 0.03 \mathrm{ng} / \mathrm{ml}$ on day 14, respectively (Figure 10). Testosterone concentration in the control group was unchanged over time. The gradual reduction $(P<0.05)$ in serum testosterone concentration might be due to the degeneration in the interstitial cells of Leydig that resulted from use of the sterilants. The disorganization of testicular parenchyma as observed microscopically is supported by other studies using $\mathrm{CaCl}_{2}$ (Jana et al., 2002, 2005) and $\mathrm{NaCl}$ (Neto et al., 2014) for chemical castration. But the significantly lower reduction $(P<0.05)$ in group $\mathrm{C}$ bucks than in those of groups $\mathrm{A}$ and $\mathrm{B}$ may be because $\mathrm{C}_{6} \mathrm{H}_{8} \mathrm{O}_{7}$ caused less testicular tissue damage.

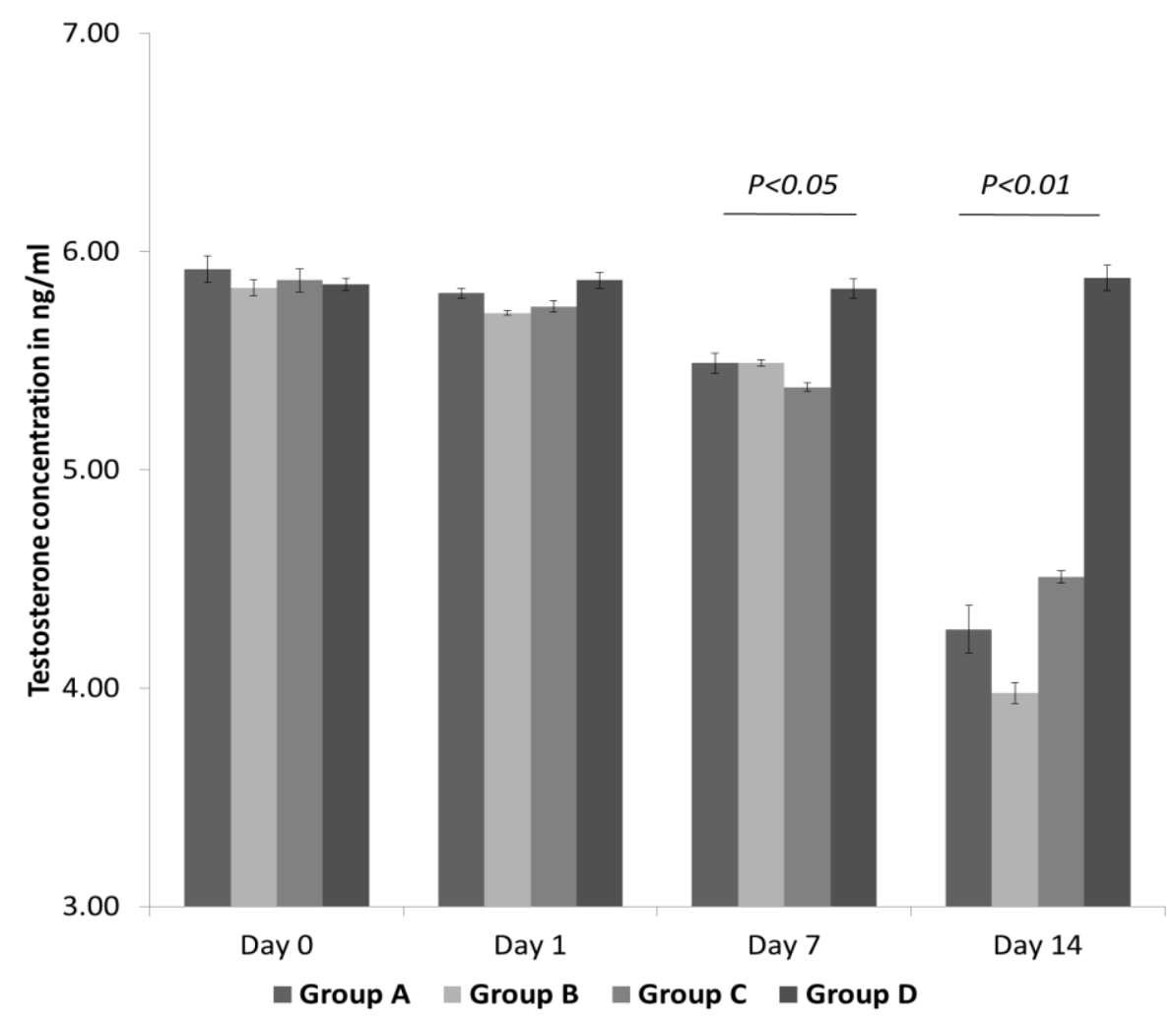

Figure 10 Variation in testosterone concentration $(\mathrm{ng} / \mathrm{ml})$ in serum samples collected on day 0 before intratesticular injection, and on days 1, 7 and 14

Group A: intra-testicular injection of $30 \%$ calcium chloride solution, Group B: intra-testicular injection of $25 \%$ sodium chloride solution, Group C: intra-testicular injection of $50 \%$ citric acid solution, Group D intra-testicular injection of deionized water

A significant elevation $(P<0.05, \mathrm{~F}=8.09)$ of $\mathrm{LH}$ concentration in serum from $8.51 \pm 0.15 \mathrm{mlU} / \mathrm{ml}, 9.13$ $\pm 0.97 \mathrm{mlU} / \mathrm{ml}$ and $8.08 \pm 0.29 \mathrm{mlU} / \mathrm{ml}$ on day 0 to $11.66 \pm 0.55 \mathrm{mlU} / \mathrm{ml}, 11.83 \pm 0.83 \mathrm{mlU} / \mathrm{ml}$ and $11.71 \pm$ $0.16 \mathrm{mIU} / \mathrm{ml}$ on day 14 was observed in group $\mathrm{A}, \mathrm{B}$, and $\mathrm{C}$, respectively (Figure 11$)$. The elevation $(P<0.05)$ in the serum LH concentration in the bucks may be because of withdrawal of the negative feedback effect of testosterone on the hypothalamo-pituitary axis (Tillbrook \& Clarke, 2001). Jana et al. (2005) also reported that the elevation in the LH concentration was owing to a gradual decrease in the testosterone concentration. 


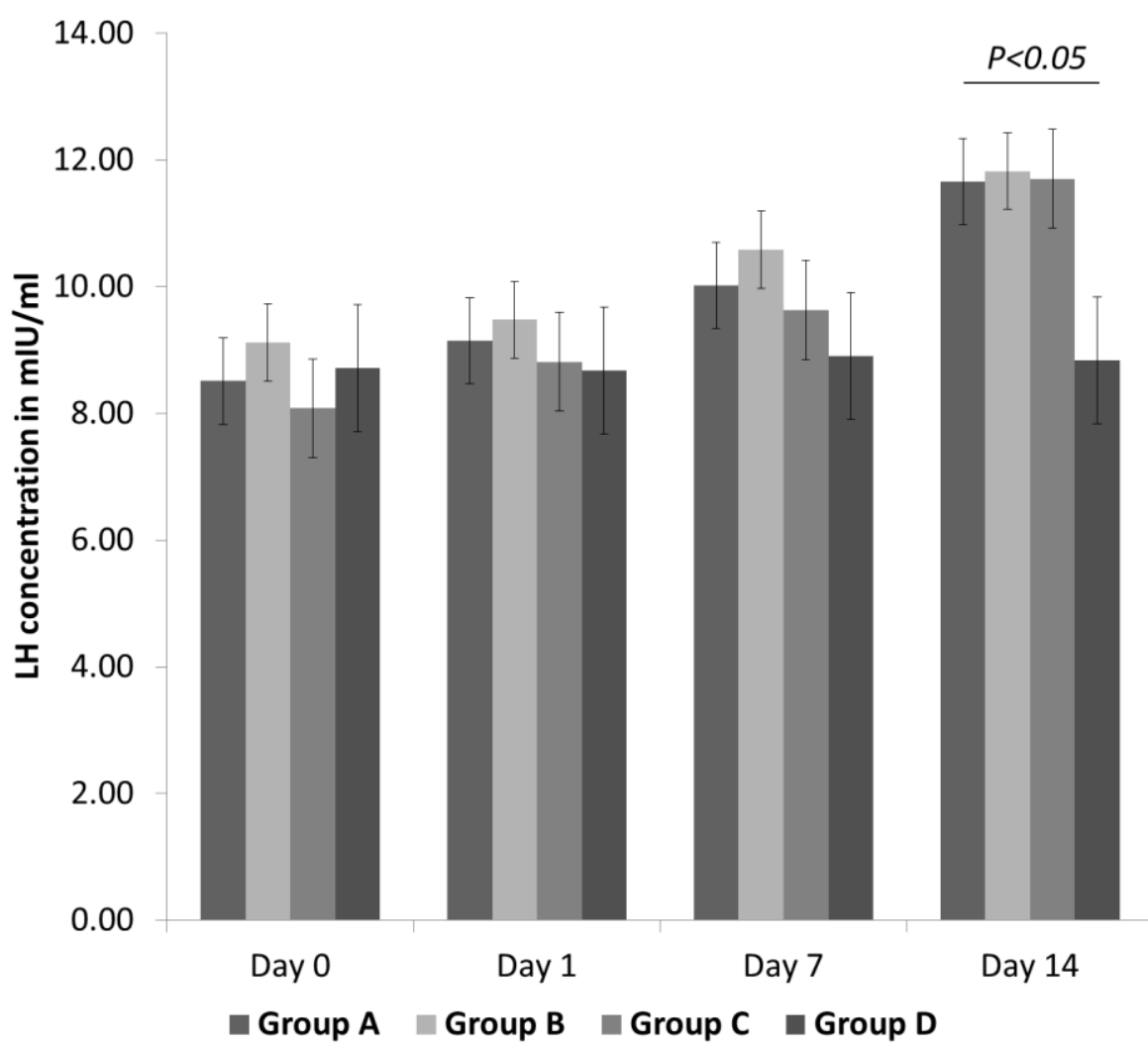

Figure 11 Variation in luteinizing hormone concentration $(\mathrm{mlU} / \mathrm{ml})$ in serum samples obtained at days 0,7 and 14 among all groups

Group A: intra-testicular injection of $30 \%$ calcium chloride solution, Group B: intra-testicular injection of $25 \%$ sodium chloride solution, Group C: intra-testicular injection of $50 \%$ citric acid solution, Group D intra-testicular injection of deionized water

\section{Conclusions}

The pathological changes and absence of spermatozoa in the TFNA slide samples indicate bilateral intra-testicular injections of calcium chloride and sodium chloride are seemingly more effective than citric acid in inducing chemical-based castration. However, the changes in the concentration of testosterone and LH caused by the chemosterilants were similar, indicating similar effectiveness of the agents.

\section{Acknowledgments}

Funding for this work was provided by the Ministry of Science and Technology, Government of the People's Republic of Bangladesh through National Science and Technology Fellowship/2015-2016 (Grant No. 93.012.002.01.03.022-2015-437-198/210)

\section{Authors' Contributions}

$\mathrm{MH}$ designed the experiment, was involved in every step, and drafted the manuscript. MAHM participated in chemical sterilization of bucks, sample collection and preparation of slides for the histomorphological study. MMA contributed to critical checking of this manuscript. NSJ supervised throughout the experiment and provided valuable suggestions.

\section{Conflict of Interest Declaration}

The authors declare there was no conflict of interest in the subject matter or materials discussed in this manuscript.

\section{References}

Bakir, B., Gulyuz, F., Karaca, F., Yuksel, H., Sahin, A. \& Uslu, B.A., 2002. Chemical castration in dogs. J. of H. Sci. 8(12), 6-9.

Bretschneider, G., 2005. Effects of age and method of castration on performance and stress response of beef male cattle: A review. Livest. Prod. Sci. 97, 89-100. 
Cavalieri, J., 2017. Chemical sterilisation of animals: A review of the use of zinc- and $\mathrm{CaCl}_{2}$ based solutions in male and female animals and factors likely to improve responses to treatment. Anim. Repro. Sci. 181, 1-8.

Currah, J.M., Hendrick, S.H. \& Stookey, J.M., 2009. The behavioral assessment and alleviation of pain associated with castration in beef calves treated with flunixin meglumine and caudal lidocaine epidural anesthesia with epinephrine. Can. Vet. J. 50, 375-382.

Dixit, V.P., Lohiya, N.K., Arya, M. \& Argrawal, M., 1975. Chemical sterilization of male dogs after a single intra-testicular injection of 'Danazol'. Folia Biol. 23(3), 305-310.

Emir, L., Dadalı, M., Sunay, M., Erol, D., Çaydere, M. \& Üstün, H., 2008. Chemical castration with intra-testicular injection of $20 \%$ hypertonic saline: A minimally invasive method. Urol. Oncol. 26, 392-396.

Fahim, M.S., Fahim, Z. \& Harman \& J.M., 1982. Chemical sterilization in the male part I: Rats. Arch. Androl. 9(3), 261265.

Fordyce, G., Hodge, P.B., Beaman, N.J., Laing, A.R., Campero, C. \& Shepherd, R.K., 1989. An evaluation of calf castration by intra-testicular injection of a lactic acid solution. Aus. Vet. J. 66, 272-276.

Foresta, C., 1993. Citologia testicolare per agoaspirazione nella diagnostic dell'infertilitá maschile. Piccin Nuova Libreria, Padova.

Hasan, M., Miah, M.A.H., Rosy, T.A., Jha, P.K. \& Juyena, N.S., 2016. Serum testosterone concentration in surgically castrated Black Bengal bucks. BD Vet. 32(2), 71-77.

ljaz, A., Abalkhail, A.A. \& Khamas, W.A.H., 2000. Effect of intra-testicular injection of formalin on seminiferous tubules in Awassi lambs. Pak. Vet. J. 20(3). 129-134.

Immegart, H.M. \& Threlfall, W.R., 2000. Evaluation of intra-testicular injection of glycerol for non-surgical sterilization of dogs. Am. J. of Vet. Res. 61, 544-549.

Jana, K. \& Samanta, P.K., 2011. Clinical evaluation of non-surgical sterilization of male cats with single intra-testicular injection of calcium chloride. BMC Vet. Res. 7, 39.

Jana, K., Samanta, P.K. \& Ghosh \& D., 2002. Dose dependent response to an intra-testicular injection of calcium chloride for induction of chemosterilization in adult albino rats. Vet. Res. Commun. 26, 651-673.

Jana, K., Samanta, P.K. \& Ghosh, D., 2005. Evaluation of single intra-testicular injection of calcium chloride for nonsurgical sterilization of male Black Bengal goats (Capra hircus): A dose-dependent study. Anim. Repro. Sci. 86, 89-108.

Kar, A., Kamboj, V. \& Goswami, A., 1965. Sterilization of male rhesus monkeys by iron salts. J Repro. Fertil. 9, 115-117..

Kar, A.B., 1961. Chemical sterilization of male rhesus monkeys. Endocrinol. 69, 1116-1119.

Koger, L.M., 1978. Calcium chloride castration. Mod. Vet. Pract. 59(2), 119-121.

Larkin, H.A., 1994. Veterinary cytology - Fine needle aspiration of masses or swellings on animals. Irish Vet. J. 47, 6573.

Leoci, R., Aiudi, G., Silvestre, F., Lissner, E.A. \& Lacalandra, G.M., 2014. Alcohol diluent provides the optimal formulation for calcium chloride non-surgical sterilization in dogs. Acta Vet. Scand. 56(1), 62.

Martins, L.T., Gonçalves, M.C., Tavares, K.C.S., Gaudêncio, S., Santos Neto, P.C., Dias, A.L.G., Gava, A., Saito, M.E., Oliveira, C.A., Mezzalira, A. \& Vieira, A.D., 2011. Castration methods do not affect weight gain and have diverse impacts on the welfare of water buffalo males. Livest. Sci. 140(1), 171-176.

Mitra, B. \& Samanta, P.K., 2000. Testicular degeneration of scrub bulls by calcium chloride. Ind. J. of Vet. Surg. 21, 3738.

Mohammed, A. \& James, F.O., 2013. Chemical castration by a single bilateral intra-testicular injection of chlorhexidine gluconate and cetrimide in bucks. Sokoto Journal of Veterinary Sci. 11(1), 62-65.

Naz, R.K. \& Talwar, G.P., 1981. Immunological sterilization of male dogs by BCG. Int. J. Androl. 4, 111-128.

Neto, O.A., Gasperin, B.G., Rovani, M.T., Ilha, G.F., Nóbrega, J.E. Jr., Mondadori, R.G., Gonçalves, P.B. \& Antoniazzi, A.Q., 2014. Intra-testicular hypertonic sodium chloride solution treatment as a method of chemical castration in cattle. Theriogenology 82, 1007-1011.

Oliveira, F.C., Ferreira, C.E.R., Haas, C.S., Oliveira, L.G., Mondadori, R.G., Schneider, A., Rovani, M.T., Gonçalves, P.B.D., Vieira A.D., Gasperin, B.G. \& Lucia Jr, T., 2017. Chemical castration in cattle with intra-testicular injection of sodium chloride: Effects on stress and inflammatory markers. Theriogenology 90, 114-119.

Stafford, K.J. \& Mellor, D.J., 2005. The welfare significance of the castration of cattle: A review. NZ Vet. J. 53, 271-278.

Stelletta, C., Juyena, N.S., Ponce Salazar, D., Ruiz, J. \& Gutierrez, G., 2011. Testicular cytology of alpaca: Comparison between impressed and smeared slides. Anim. Repro. Sci. 125, 133-137.

Talukder, M.R.I., Hasan, M., Rosy, T.A., Bari, F.Y. \& Juyena, N.S., 2018. Monitoring vaginal electrical resistance, follicular wave, and hormonal profile during oestrus cycle in transition period in Bangladeshi sheep. J. Vet. Res. $62,571-579$.

Tepsumethanon, V., Wilde, H. \& Hemachudha, T., 2005. Intra-testicular injection of balanced zinc solution for permanent sterilization of dogs. J. of Medical Assoc of Thailand 88 (5), 686- 689.

Tillbrook, A.J. \& Clarke, I.J., 2001. Negative feedback regulation of the secretion and actions of gonadotrophins releasing hormone in males. Biol. Repro. 64, 735-742. 